\title{
ADOPSI INTERNATIONAL FINANCIAL REPORTING STANDART (IFRS) TERHADAP KUALITAS LABA
}

\author{
Ermina Sari \\ ina80724@gmail.com, STIE Al-Madani, Indonesia
}

\begin{abstract}
Abstrak
Penelitian ini menguji pengaruh Adopsi International Financial Reporting Standart (IFRS) terhadap kualitas laba. Variabel dalam penelitian ini adalah IFRS yang diukur dengan dummy yaitu nilai 0 untuk periode sebelum adopsi IFRS (2008-2011) serta nilai 1 untuk periode setelah penerapan adopsi IFRS (2013-2016). Kualitas laba yang diukur dengan nilai discretionary accrual dan variabel kontrol yaitu rasio hutang dan ukuran perusahaan. Dengan sampel perusahaan manufaktur yang terdaftar di BEI.Periode penlitian 2008-2016 diperoleh sampel 32 perusahaan dengan total 256 observasi penelitian. Pengujian dilakukan dengan regresi linier berganda mengunakan alat uji eviews 9 . Hasil penelitian ini menunjukan bahwa IFRS tidak berpengaruh signifikan terhadap kualitas laba yang diukur dengan discretionary accrual yang ditunjukan dengan nilai signifikasi sebesar 0,2914>0,05. Sedangkan untuk variabel kontrol rasio hutang pengaruh positif signifikan terhadap discretionary accrual. Ukuran perusahaan memiliki pengaruh yang negatif signifikan terhadap discretionary accrual. Artinya Adopsi IFRS tidak berpengaruh terhadap kualitas laba, variabel kontrol rasio hutang berpengaruh negatif terhadap kualitas laba perusahaan, sedangkan ukuran perusahaan berpengaruh positif terhadap kualitas laba.
\end{abstract}

KataKunci : Adopsi IFRS, Kualitas Laba, Manajemen Laba.

\section{Abtrack}

This study examines the effect of Adoption of International Financial Reporting Standards (IFRS) on earnings quality. The variable in this study is IFRS which is measured by dummy which is the value of 0 for the period before IFRS adoption (2008-2011) and the value of 1 for the period after the adoption of IFRS adoption (2013-2016). The quality of earnings is measured by the value of discretionary accruals and control variables, namely the debt ratio and company size. With a sample of manufacturing companies listed on the IDX. The 2008-2016 research period obtained a sample of 32 companies with a total of 256 research observations. Tests carried out by multiple linear regression using eviews 9. Test results. The results of this study indicate that IFRS has no significant effect on earnings quality as measured by discretionary accruals indicated by a significance value of 0.2914>0.05. Whereas the debt ratio control variable has a significant positive effect on discretionary accruals. Firm size has a significant negative effect on discretionary accruals. This means that IFRS adoption has no effect on earnings quality, debt ratio control variables have a negative effect on the quality of corporate earnings, while firm size has a positive effect on earnings quality.

Keywords: IFRS Adoption, Profit Quality, Profit Management. 


\section{Pendahuluan}

Sebagai salah satu langkah dalam meningkatkan kredibilitas serta komparabilitas pelaporan keuagan, pada tahun 1994 Ikatan Akuntansi Indonesia ( IAI) telah melaksanakan program harmonisasi dan adaptasi standar akuntansi international dalam rangka pengembangan standar akuntansinya. Pada tahun 2008 IAI telah melakukan pengumuman rencana konvergensi standar akuntansi lokal yaitu Pernyataan Standar Akuntansi (PSAK) dengan InternationalFinancial Reporting Standart (IFRS).Dalam hal konvergensi IFRS ini, Indonesia melakukannya dengan tiga tahapan. Dimulai dengan tahap adopsi pada tahun 2008 hingga tahun 2010, kemudian tahap persiapan akhir pada tahun 2011, dan yang terakhir adalah tahap implementasi pada tahun 2012. Dan pada tahun 2012 pula, IAI berencana untuk melakukan evaluasi dampak penerapan PSAK berbasis IFRS secara komprehensif.

Keberhasilan implementasi IFRS, memiliki manfaat yang melebihi biaya, mempengaruhi tidak hanya perusahaan dalam Uni Eropa, tetapi juga perusahaan-perusahaan di seluruh dunia, sehingga mampumembuat IFRS semakin menjadi standar pelaporan global (Capkun et al., 2011). Penerapan IFRS diklaim akan memberi manfaat bagi peningkatan kualitas laporan keuangan. Menurut (Iatridis, 2010) laporan keuangan yang berkualitas dapat dilihat dari berkurangnya praktek manajemen laba dan meningkatnya relevansi nila informasi akuntansi.Upaya mengurangi manajemen laba yaitu dengan melakukan koreksi terhadap standar akuntansi.Perbaikan standar akuntansi yang saat ini sedang menjadi isu adalah adopsi International Financial Reporting Standard (IFRS). (Courtenay, 2008) mengungkapkan salah satu isu dari IASB adalah bahwa IFRS bertujuan untuk menyederhanakan berbagai alternatif kebijakan akuntansi yang diperbolehkan dan diharapkan dapat membatasi pertimbangan kebijakan manajemen (management's discretion) terhadap manipulasi laba sehingga dapat meningkatkan kualitas laba.

IFRS merupakan standar yang menggunaan Principle Based dalam perlakuan akuntansi. Penggunaan principle based akan mengurangi kemungkinan munculnya aturan baru yang melengkapi aturan yang sudah ada. Munculnya aturan-aturan baru akan memberikan kesempatan kepada manajemen melakukan income smoothing yang memicu munculnya manajemen laba.Kewajiban untuk menggunakan IFRS bagi perusahaan-perusahaan yang terdaftar di bursa efek merupakan salah satu perubahan paling signifikan dalam sejarah regulasi akuntansi (Daske, Leuz and Leuz, 2008). Regulator berharap bahwa penggunaan IFRS dapat meningkatkan komparabilitas laporan keuangan, meningkatkan transparansi perusahaan dan kualitas pelaporan keuangan sehingga menguntungkan investor (Hariyani, 2015)

Penelitian mengenai dampak adopsi IFRS terhadap kualitas laba yang dikukur dengan manajemen alaba telah dilakukan oleh peneliti-peneliti sebelumnya. Seperti penelitian yang dilakukan oleh (Jeanjean and Stolowy, 2008) yang menyatakan bahwa penerapan standar IFRS berdampak pada kualitas laba khususnya manajemen laba dengan melakukan observasi pada 1.146 perusahaan dari Australia, Prancis, dan UK mulai tahun 2005 hingga 2006. Berbeda denganhasil penelitian (Kristanto, Septian Bayu; Tarigan, Krinawati; Tarigan, 2014), menunjukan bahwa Konvergensi IFRS berpengaruh negatif dan tidak signifikan terhadap kualitas laba setelah konvergensi IFRS. Hasil yang sama ditunjukan oleh penelitian (Eka, 2014) menunjukan hasil sebalinya yaitu, IFRS tidak berpengaruh terhadap manajemen laba.

Hasil penelitian sebelumnya telah menunjukan ketidak konsistenan mengenai dampak adopsi IFRS terhadap kualitas laba yang diukur dengan manajemen laba. Selain itu, dikutip melalui situs resmi IAI (iaiglobal.or.id) IAI sebagai standart setter di Indonesia, melalui Dewan Standar Akuntansi Keuangan (DSAK-IAI) telah berkomitmen untuk menjaga gap antara IFRS 
dan PSAK hanya untuk satu tahun. Implikasinya banyak standar baru yang dikeluarkan oleh IASB yang akan efektif pada tahun 2018, harus diadopsi di Indonesia pada 2019. Dengan demikian Indonesia semakin gencar melakukan program adopsi IFRS sehingga dirasa perlu untuk melakukan penelitian mengenai dampak adopsi IFRS terhadap pengguna laporan keuangan sehingga dapat dijakdikan sebagai bahan evaluasi pengguna laporan keuangan.

\section{Landasan teori dan Pengembangan Hipotesis Teori agency}

Teori agensi menyatakan bahwa apabila terdapat pemisahan antara pemilik sebagai prinsipal dan manajer sebagai agen yang menjalankan perusahaan maka akan muncul permasalahan agensi karena masing-masing pihak tersebut akan selalu berusaha untuk memaksimalisasikan fungsi utilitasnya (Jensen, M. C., 1976). Penerapan IFRS memiliki pengaruh besar pada pelaporan keuangan perusahan dan kinerja perusahaan. Pengadopsian standar akuntansi internasional ke dalam standar akuntansi domestik bertujuan meningkatkan kredibilitas laporan keuangan, meningkatkan persyaratan item-item pengungkapan sehingga akan terjadi peningkatan nilai perusahaan, meningkatkan akuntanbilitas manajemen dalam menjalankan perusahaan, menghasilkan informasi laporan keuangan yang lebih relevan, akurat, dan dapat diperbandingkan serta menghasilkan informasi yang valid untuk aktiva, hutang, ekuitas, pendapatan dan beban perusahaan (Petreski, 2007).

Menurut (Widyaningdyah, 2001) agency theory masing-masing individu semata-mata termotivasi oleh kepentingan dirinya sendiri sehingga menimbulkan konflik kepentingan antara principaldan agent. Pihak principal termotivasi mengadakan kontrak untuk mensejahterakan dirinya dengan profitabilitas yang selalu meningkat.Agent termotivasi untuk memaksimalkan pemenuhan kebutuhan ekonomi dan psikologisnya, antara lain dalam memperoleh investasi, pinjaman, maupun kontrak kompensasi. Konflik kepentingan semakin meningkat terutama karena principal tidak dapat memonitor aktivitas agen (CEO) sehari-hari untuk memastikanbahwa agen bekerja sesuai dengan keinginan pemegang saham.

Teori agensi menyatakanbahwa praktik manajemen laba dipengaruhi oleh adanya konflik kepentingan antara manajemen dengan pemilik modal yang timbul karena masing-masing pihak berusahauntuk mencapai tujuan yang berkaitan denganpencapaian kemakmurannya. Posisi, fungsi, situasi, tujuan, kepentingan dan latar belakang prinsipal dan agen yang berbeda dan saling bertolak belakang tersebut akan menimbulkan pertentangan dengan saling tarik menarik kepentingan (conflict of interest) dan pengaruh antara satu sama lain.

\section{PengaruhAdopsi IFRS terhadap Kualitas Laba.}

(Hodge, 2003) definisi kualitas laba sebagai "the extent to which net 15 income reported on the income statement differs from "true" (unbiased and accurate) earnings" . (Schipper, K. and Vincent, 2003) mengelompokkan konstruk kualitas laba dan pengukurannya berdasarkan cara menentukan kualitas laba, yaitu berdasarkan: sifat runtun-waktu dari laba, karakteristik kualitatif dalam rerangka konseptual, hubungan laba-kas-akrual, dan keputusan implementasi.Kualitas laba didasarkan pada hubungan laba-kas-akrual yang dapat diukur dengan berbagai ukuran, yaitu: rasio kas operasi dengan laba, perubahan akrual total, estimasi abnormal/discretionary accruals (akrual abnormal/ DA), dan estimasi hubungan akrual-kas.

IFRS mensyaratkan pengungkapan berbagai informasi tentang risiko baik kualitatif maupun kuantitatif.Pengungkapan dalam laporan keuangan harus sejalan dengan data/informasi yang dipakai untuk pengambilan keputusan yang diambil oleh manajemen. Tingkat 
pengungkapan yang makin mendekati pengungkapan penuh akan mengurangi tingkat asimetri informasi (ketidakseimbangan informasi) ketidakseimbanagan informasi antara manajer dengan pihak pengguna laporan keuangan.

Upaya mengurangi manajemen laba yaitu dengan melakukan koreksi terhadap standar akuntansi.Perbaikan standar akuntansi yang saat ini sedang menjadi isu adalah adopsi International Financial Reporting Standard (IFRS).(Courtenay, 2008) mengungkapkan salah satu isu dari IASB adalah bahwa IFRS bertujuan untuk menyederhanakan berbagai alternatif kebijakan akuntansi yang diperbolehkan dan diharapkan dapat membatasi pertimbangan kebijakan manajemen (management's discretion) terhadap manipulasi laba sehingga dapat meningkatkan kualitas laba.

IFRS merupakan standar yang menggunaan Principle Based dalam perlakuan akuntansi. Penggunaan principle based akan mengurangi kemungkinan munculnya aturan baru yang melengkapi aturan yang sudah ada. Munculnya aturan-aturan baru akan memberikan kesempatan kepada manajemen melakukan income smoothing yang memicu munculnya manajemen laba. Kewajiban untuk menggunakan IFRS bagi perusahaan-perusahaan yang terdaftar di bursa efek merupakan salah satu perubahan paling signifikan dalam sejarah regulasi akuntansi (Daske, Leuz and Leuz, 2008).

Mengenai dampak pengadopsian IFRS terhadap manajemen laba, telahdilakukan oleh beberapa peneliti sebelumnya. Seperti penelitian yang dilakukan (Nnadi and Nwobu, 2016), meneliti mengenai dampak IFRS terhadap manajemen laba pada perbankan Nigeria.Hasil penelitian tersebut menunjukan adanya penurunan manajemen laba pada perbankan di Nigerian. Hasil berbeda ditunjukan oleh penelitian yang dilakukan (Jeanjean and Stolowy, 2008) yang manajemen laba di negara-negara tersebut tidak mengalami penurunan setelah adanya keharusan mengadopsi IFRS, dan bahkan meningkat untuk Prancis.

Penelitian mengenai dampak adopsi IFRS di Indonesia juga telah diteliti oleh penelitipeneliti sebelumnya, seperti (Kristanto, Septian Bayu; Tarigan, Krinawati; Tarigan, 2016), hasil penelitiannya menunjukan bahwa Konvergensi IFRS berpengaruh negatif dan tidak signifikan terhadap kualitas laba. Sejalan dengan hasil penelitian (Eka, 2014) menunjukan hasil sebalinya yaitu, IFRS tidak berpengaruh terhadap manajemen laba. Secara umum, revisi tujuh PSAK di bawah program konvergensi IFRS tidak menyebabkan perubahan signifikan dalam kebijakan akuntansi perusahaan dan dapat menjelaskan mengapa adopsi IFRS tidak memiliki pengaruh pada manajemen laba untuk tahun 2010. Hasil penelitian yang sama diperoleh dari hasil penelitian (Santy, Tawakkal and Pontoh, 2013) yang menyatakan bahwa adopsi IFRS tidak berpengaruh signifikan terhadap manajemen laba. Kewajiban untuk menggunakan IFRS bagi perusahaan-perusahaan yang terdaftar di bursa efek merupakan salah satu perubahan paling signifikan dalam sejarah regulasi akuntansi (Daske, Leuz and Leuz, 2008). Regulator berharap bahwa penggunaan IFRS dapat meningkatkan komparabilitas laporan keuangan, meningkatkan transparansi perusahaan dan kualitas pelaporan keuangan sehingga menguntungkan investor (Hariyani, 2015). 


\section{Model Penelitian}

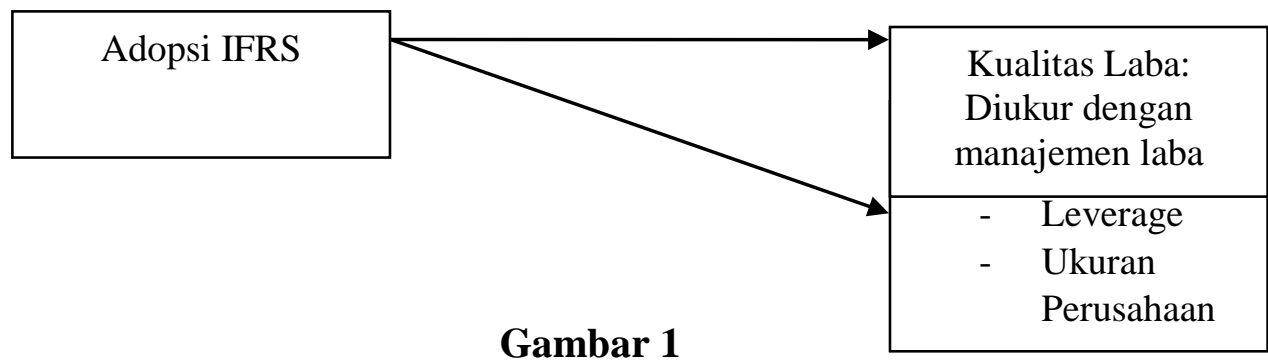

Pengaruh IFRS terhadap Kualitas Laba

\section{Meteodelogi Penelitian sampel}

Dalam penelitian ini yang menjadi objek penelitian adalah perusahaan manufaktur yang terdapat di Bursa Efek Indonesia dengan periode pengamatan 2008-2016 (2008-2011 sebelum dan 2012-2016 setelah adopsi IFRS).Perusahaan manufaktur menjadi sampel dikarenakan (Cahyonowati and Ratmono, 2011) penelitian yang memfokuskan pada pengujian sampel pada satu industri saja dapat mengontrol variabel pengganggu.

Data yang digunakan adalah data sekunder, penulis mendapatkan data secara tidak langsung yaitu melalui perantara orang lain dan dokumen yang mendukung penelitian.Penulis menggunakan laporan keuangan tahunan yang diperoleh dengan cara mendownload dari website Bursa Efek Indonesia (www.idx.co.id. Pemilihan sampel dilakukan dengan metode purposive sampling sehingga diperoleh 32 perusahaan dengan tahun penelitian 8 tahun (4 tahun sebelum dan 4 tahun sesudah) maka observasi penelitian ini berjumlah 256.

\section{Definisi operasional variabel Kualitas Laba}

(Hodge, 2003) definisi kualitas laba sebagai "the extent to which net 15 income reported on the income statement differs from "true" (unbiased and accurate) earnings". Kelompok penentuan kualitas laba ini dapat diikhtisarkan sebagai berikut.: 1. Berdasarkan sifat runtunwaktu laba, kualitas laba meliputi: persistensi, prediktabilitas (kemampuan prediksi), dan variabilitas. 2. Kualitas laba didasarkan pada hubungan laba-kas-akrual yang dapat diukur dengan berbagai ukuran, yaitu: rasio kas operasi dengan laba, perubahan akrual total, estimasi abnormal/discretionary accruals (akrual abnormal/ DA), dan estimasi hubungan akrual-kas.

Dalam penelitian ini, kualitas laba di proxikan dengan nilai Discretionary accruals perusahaan. Sebagaimana mengacu pada penelitian sebelumnya yaitu (Kristanto, Septian Bayu; Tarigan, Krinawati; Tarigan, 2016). Nilai akrual diskresioner diestimasi dengan menggunakan modified jones model oleh (Dechow et al., 1995). Dengan rumus sebagai berikut:

Keterangan :

$$
\mathbf{D A}_{i t}=\text { TA }_{i t}-\text { NDA }_{i t}
$$

$\mathrm{DA}_{\text {it }} \quad$ : Discretionary accruals perusahaan i pada periode $\mathrm{t}$

$\mathrm{TA}_{\mathrm{it}} \quad$ : Total accruals perusahaan i pada periode $\mathrm{t}$

$\mathrm{NDA}_{\mathrm{it}} \quad$ : NonDiscretionary accrualsperusahaan i pada periode $\mathrm{t}$ 
Dimana untuk menentukan nilai Total Accrual dihitung dengan rumus sebagai berikut:

$$
\mathbf{T A}_{i \mathrm{i}}=\mathrm{NI}_{\mathrm{it}}-\mathrm{CFO}_{\mathrm{it}}
$$

Keterangan :

$\mathrm{TA}_{\text {it }} \quad$ : Total accrualsperusahaan i pada periode $\mathrm{t}$

$\mathrm{NI}_{\mathrm{it}} \quad$ : Laba bersih perusahaan i pada periode $\mathrm{t}$

$\mathrm{CFO}_{\text {it }} \quad$ : Arus kas operasi perusahaan i pada periode $\mathrm{t}$

Sementara untuk menentukan nilai NonDiscretionary accruals dihitung dengan rumus sebagai berikut:

NDAit $=\alpha_{1}\left(1 / A_{i t-1}\right)+\alpha_{2}\left(\Delta R E V_{i t} / A_{i t-1}-\Delta R E C_{i t} / A_{i t-1}\right)+\alpha_{3}\left(P_{P E} / / A_{i t-1}\right)$

Keterangan :

$\mathrm{NDA}_{\mathrm{it}} \quad$ : NonDiscretionary accrualsperusahaan i pada periode $\mathrm{t}$

$\mathrm{A}_{\mathrm{it}-1} \quad$ : Total aset total perusahaan i pada periode $\mathrm{t}-1$

$\triangle \mathrm{REV}_{\text {it }} \quad$ : Perubahan revenueperusahaan i pada periode ke $\mathrm{t}$

$\mathrm{PPE}_{\mathrm{it}} \quad$ : Aktiva tetap perusahaan i pada periode ke $\mathrm{t}$

$\triangle \mathrm{REC}_{\mathrm{it}} \quad$ : Perubahan piutang dagang perusahaan i pada periode $\mathrm{t}$

Menghitung Discretionary Accruals (DA) :

Keterangan:

$$
\text { DAit }=\text { TAit }- \text { NDAit }
$$

$\mathrm{DA}_{\mathrm{it}}$ : Discretionary accruals perusahaan i pada periode waktu $\mathrm{t}$

$\mathrm{TA}_{\mathrm{it}}$ : Total akrual perusahaan i pada periode waktu $\mathrm{t}$

$\mathrm{NDA}_{\text {it }}$ : Non discretionary accruals perusahaan i pada periode $t$

Pengukuran kualitas laba berdasarkan tingkat discretionary accrual yang ditangkap dalam nilai absolut dari nilai residual.

\section{Variabel Independen}

Adopsi IFRS

Variabel independen dalam penelitian ini adalah penerapan penerapan Adopsi IFRS di Indonesia,dimana pengukuran variabel ini mengikuti penelitian sebelumnya yaitu (Santy, Tawakkal and Pontoh, 2013).Variabel ini diukur dengan variabel dummy yaitu nilai 0 untuk periode sebelum adopsi IFRS (2008-2011) serta nilai 1 untuk periode setelah penerapan adopsi IFRS (2013-2016).

\section{Variabel Kontrol}

Variabel kontrol yaitu variable yang digunakan untuk melengkapi atau mengontrol hubungan kausalnya supaya lebih baik untuk didapatkan model empiris yang lebih lengkap dan lebih baik. Agar variabel pengganggu tidak biasmempengaruhi hasil dari pengujian tersebut (Hartono, 2007), didalam penelitian ini digunakan variabel kontrol yaitu Rasio hutang dan Ukuran Perusahaan (Size).

\section{Metode Analisis Data}

Dalam metode estimasi model regresi dengan menggunakan data panel dapat dilakukan melalui tiga pendekatan, yaitu Common Effect Model atau Pooled Least Square (PLS), Fixed Effect Model (FE) dan Random Effect Model (RE). Dan untuk memilih model yang paling tepat 
terdapat beberapa pengujian yang dapat dilakukan yaitu dengan uji Chow, uji Hausman dan uji uji Lagrange Multiplier (Gujarati dan Porter, 2015).

\section{Uji regresi linier berganda}

Uji hipotesis dalam penelitian ini menggunakan regresi linier berganda. Persamaan regresi yang digunakan dalam penelitian ini adalah :

Keterangan :

$$
\mathrm{KL}_{-} \mathrm{DA} A_{\mathrm{it}}=\alpha+\beta_{1} \mathrm{IFRS}+\beta_{2} \mathrm{LEV}_{\mathrm{it}}+\beta_{3} \mathrm{LnSIZE}_{\mathrm{it}}+e
$$

KL_DA :Kualitas laba yang diukur dengan discretionary accrual yang dihitung menggunakan model modified jones model oleh (Dechow et al., 1995) .

IFRS : Dummy 1 untuk setelah penerapan adopsi IFRSdan 0 sebelum adopsi IFRS

LEV : Variabel kontrol rasio Hutang (Leverage)

LnSize : Variabel control Logaritma Natural total Asset

\section{Hasil dan Diskusi}

Hasil pengolahan data dibagi menjadi dua bagian yaitu periode sebelum adopsi IFRS (2008-2011) dan periode setelah adopsi IFRS (2013-2016) dalam penelitian ini terdapat time lag yaitu tahun 2012 yaitu tahun pertama kali penerapan PSAK yang sudah mengadopsi seluruh IFRS. Hasil statistik deskriptif dan hasil pengujian hipotesis pada Tabel 1 menunjukkan hasil olah data secara deskriptif yang secara garis besar dapat diuraikan sebagai berikut.Nilai rata-rata variabel IFRS 0,5 menunjukkan bahwa sampel terbagi dua dengan merata, masing-masing 50\% sebelum dan sesudah adopsi IFRS, leverage dan total asset menunjukkan nilai yang positif, yang berarti secara rata-rata perusahaan memiliki nilai positif dari variabel-variabel tersebut.

Tabel 1. Statistik Deskripstif

\begin{tabular}{lrr}
\hline \multicolumn{1}{c}{ Variabel } & Rata-rata & Std. Dev \\
\hline KL_DA & 0.1343 & 0.0951 \\
IFRS & 0.5000 & 0.5000 \\
Lev & 0.1647 & 0.1239 \\
LnSIze & 28.518 & 1.8493 \\
& & \\
\hline
\end{tabular}

Hasil pengujian hipotesis yang diajukan, yaitu terdapat peningkatan kualitas laba setelah pengadopsian IFRS, dapat dilihat pada Tabel 2. 
Tabel 2 Dampak penerapan IFRS terhadap kualitas laba

$$
\text { IFRS terhadap Kualitas laba }
$$

\begin{tabular}{lll}
\cline { 2 - 3 } \multicolumn{1}{r}{ Variabel } & \multicolumn{2}{c}{ Prob. } \\
\cline { 2 - 3 } & Coeff. & 0.1248 \\
\hline C & -0.1524 & 0.2914 \\
IFRS & -0.0185 & $0.0910^{*}$ \\
Lev & 0.0631 & $0.0315^{* *}$ \\
LnSize & -0.0301 &
\end{tabular}

Ket: Variabel dependen: DA.C = konstanta; IFRS: Adopsi

IFRS, Lev: Leverage; LnSize: Ukuran perusahaan; $\mathrm{n}=256$; adjusted $\mathrm{R}^{2}=0.343, \mathrm{~F}=0.0000 . * \operatorname{Sig}{ }^{`} 10 \%, * * \operatorname{Sig} 5 \%$

Dari Tabel 2 dapat dilihat bahwa nilai probabilitas IFRS memiliki arah negatif terhadap Discretionary accruals akan tetapi tidak memiliki pengaruh yang signifikan ( $\mathrm{p}$ value $=0,2914$ yang mengindikasikan bahwa adopsi IFRS tidak berpengaruh terhadapa kualitas laba yang diukur dengan nilai Discretionary accruals . Hasil penelitian ini tidak sejalan dengan penelitian sebelumnya yaitu (Nnadi and Nwobu, 2016). Akan tetapi hasil penelitian ini sejalan dengan penelitian (Jeanjean and Stolowy, 2008) (Santy, Tawakkal and Pontoh, 2013) (Kristanto, Septian Bayu; Tarigan, Krinawati; Tarigan, 2016), dan (Eka, 2014). Hipotesis alternatif yang diajukan dalam penelitian ini tidak terdukung. Adopsi IFRS tidak berpengaruh signifikan terhadap kualitas laba. Menurut (Ball, Robin and Shuang, 2003) standar berkualiats tinggi tidak selalu menghasilkan informasi akuntansi yang berkualitas tinggi. Hal ini diakibatkan oleh buruknya insentif terhadap pembuat laporan keuangan dan bahwa kualitas laporan keuangan pada akhirnya ditentukan oleh faktor ekonomi dan politik di negara bersangkutan yang mempengaruhi insentif manajer dan auditor, dan bukan semata-mata ditentukan oleh standar akuntansi.

Terdapat variabel kontrol dalam penelitian ini, yaitu rasio hutang dan ukuran perusahan.. Rasio hutang memiliki pengaruh yang positif signifikan terhadap Discretionary accruals. Hal itu ditunjukan dengan nilai signifikan sebesar $0,0910>0,1$. Artinya semakin tinggi nilai rasio hutang perusahaan, maka akan tinggi pula nilai Discretionary accruals sehingga dapat menurunkan kualitas laba. Dengan demikian, rasio hutang berpengaruh negatif signifikan terhadap kualitas laba. (Press, Valipour and Moradbeygi, 2011) menyatakan bahwa hutang dalam level rendah dapat berpengaruh terhadap Discretionary accruals karena manajer cenderung menggunakan kebijakan akuntansi mereka untuk memberikan informasi pribadi tentang prospek masa depan perusahaan untuk mengurangi biaya bunga.

Hasil berbeda ditunjukan oleh variabel ukuran perusahaan yang memiliki pengaruh yang negatif dignifikan terhadap Discretionary accruals $(0,0315<0,05)$. Artinya semakin besar ukuran perusahaan, maka akan menurunkan nilai Discretionary accruals sehingga dapat meningkatkan kualitas laba. Dengan demikian, ukuran perusahaan berpengaruh positif signifikan terhadap kualitas laba. Perusahaan besar dianggap memiliki informasi yang lebih banyak dibandingkan dengan perusahaan kecil. Perusahaan besar akan mampu mengungkapkan informasi yang lebih banyak dalam rangka mengurangi resiko keagenan. Ukuran perusahaan dianggap menjadi salah satu penentu kinerja suatu perusahaan. Perusahaan yang besar mampu meningkatkan kinerja perusahaannya secara konsisten karena perusahaan besar cenderung merupakan perusahaan yang going concern, serta dianggap mampu meningkatkan dan menjaga 
kualitas labanya (Warianto, 2014). Dengan semakin berkurangnya praktik manajemn laba maka laba yang dilaporkan menjadi lebih berkualitas.

\section{Kesimpulan, Keterbatasan dan Saran Penelitian}

Berdasarkan pengujian dan pemaparan diatas, maka dapat disimpulkan bahwa adopsi IFRS tidak berpengaruh signifikan terhadap kualitas laba yang diukur dengan Discretionary accruals. Dengan demikian hipotesis yang diajukan dalam penelitian ini tidak terdukung. Rasio hutang sebagai variabel kontrol dalam penelitian ini memiliki pengaruh yang positif signifikan terhadap Discretionary accruals sedangkan ukuran perusahaan memiliki pengaruh yang negatif signifikan terhadap Discretionary accruals. Dengan demikian, rasio hutang berpengaruh menurunkan kualitas laba dan sebaliknya ukuran perusahaan berpengaruh meningkatkan kualitas aba perusahaan.

Penelitian ini masih memiliki keterbatasan dalam penelitiannya misalnya, sampel yang digunakan hanyalah perusahaan manufaktur saja sehingga penelitian ini tidak dapat digeneralisasikan. Diharapkan penelitian selanjutnya dapat memperluas sampel dan dapat menguji pengaruh adopsi IFRS terhadap masing-masing sector industry sehingga hasilnya dapat digeneralisasikan dan dibandingkan menegenai dampak IFRS pada sektor lainnya. Untuk penelitian yang akan mengunakan sampel perusahaan perbankan maka disarankan dapat menggunakan pengukuran dengan model Beaver dan Engel (1996) dikarenkan model tersebut merupakan model yang paling sesuai dalam mendeteksi manajemen laba di perusahaan perbankan.

\section{DAFTAR PUSTAKA}

Ball, R., Robin, A. and Shuang, J. (2003) 'Incentives versus standards : properties of accounting income in four East Asian countries \$’, 36, pp. 235-270. doi: 10.1016/j.jacceco.2003.10.003.

Cahyonowati, N. and Ratmono, D. (2011) 'Adopsi IFRS dan Relevansi Nilai Informasi Akuntansi', pp. 105-115.

Capkun, V. et al. (2011) 'Earnings Management and Value Relevance during the Mandatory Transition from Local GAAPs to IFRS in Europe 1 Introduction', pp. 1-63.

Courtenay, S. (2008) 'The Effect of IFRS and its Enforcement on Earnings Management : An International Comparison', (December).

Daske, H., Leuz, C. and Leuz, C. (2008) 'Mandatory IFRS Reporting Around the World : Early Evidence on the Economic Consequences Initiative on Global Markets', Journal of Accounting Research, (48), pp. 1085-1142.

Dechow, P. M. et al. (1995) 'Detecting Earnings Management', 70(2), pp. 193-225.

Eka, Y. (2014) . Pengaruh adopsi IFRS, leverage dan ukuran perusahaan terhadap manajemen laba. Jurnal Ilmu \& Riset Akuntansi Vol. 3 No. 12

Hariyani, R. M. (2015) '2) 1) 2)’, 4(2), pp. 101-120. 
Hodge, F. D. (2003) 'Investors' Perceptions of Earnings Quality, Auditor Independence, and the Usefulness of Audited Financial Information’, pp. 37-48.

Iatridis, G. (2010) 'International Financial Reporting Standards and the quality of financial statement information', International Review of Financial Analysis. Elsevier Inc., 19(3), pp. 193-204. doi: 10.1016/j.irfa.2010.02.004.

Jeanjean, T. and Stolowy, H. (2008) 'J . Account . Public Policy Do accounting standards matter? An exploratory analysis of earnings management before and after IFRS adoption', Journal of Accounting and Public Policy. Elsevier Inc., 27(6), pp. 480-494. doi: 10.1016/j.jaccpubpol.2008.09.008.

Jensen, M. C., W. H. M. (1976) 'Theory of the Firm : Managerial Behavior, Agency Costs and Ownership Structure Theory of the Firm : Managerial Behavior, Agency Costs and Ownership Structure', Journal of Financial Economics, 3(4), pp. 305-360. doi:

http://dx.doi.org/10.1016/0304-405X(76)90026-X.

Kristanto, Septian Bayu; Tarigan, Krinawati; Tarigan, M. U. (2016) 'Dampak Konvergensi Ifrs Terhadap Kualitas Labadengan Ukuran Kap Sebagai Variabel Moderasi ( Studi Pada Perusahaan Manufaktur Yang Listed Di Bei )', (July). doi: 10.13140/RG.2.1.4993.8167.

Nnadi, M. and Nwobu, O. A. (2016) 'The Impact of International Financial Reporting Standards Adoption and Banking Reforms on Earnings Management : Evidence from Nigerian Banks', 5(3). doi: 10.1504/AJAAF.2016.10004608.

Petreski, M. (2007) 'The Impact of International Accounting Standards on Firms Marjan Petreski'.

Press, I. S., Valipour, H. and Moradbeygi, M. (2011) 'Corporate Debt Financing and Earnings Quality', 1(3), pp. 139-157.

Santy, P., Tawakkal and Pontoh, G. T. (2013) 'Pengaruh Adopsi IFRS terhadap Manajemen Laba pada Perusahaan Perbankan di Bursa Efek Indonesia’, Jurnal Akuntansi.

Schipper, K. and Vincent, L. (2003) ‘Earnings Quality’, Accounting Horizons, 17, pp. 97-110.

Warianto, P. (2014) 'Pengaruh Ukuran Perusahaan, Struktur Modal, Likuiditas Dan Investment Opportunity Set ( Ios ) Terhadap Kualitas Laba Pada Perusahaan Manufaktur Yang Terdaftar Di Bei', 26(1), pp. 19-32.

Widyaningdyah, A. U. (2001). Analisis Faktor-Faktor Yang Berpengaruh Terhadap Earning Management Pada Perusahaan Go Public Di Indonesia. Jurnal Akuntansi \& Keuangan, Vol. 3, No. 2, h. 89-101. 